\title{
Identity, biology and bionomics of the Common Mormon, Papilio polytes Linnaeus (Lepidoptera: Papilionidae)
}

\author{
Revathy V. S.*and George Mathew* \\ *Forest Health division, Kerala Forest Research Institute, Peechi, Kerala, India.
}

\begin{abstract}
Investigations were made on the biology and bionomics of the common mormon, Papilio polytes Linnaeus. Morphological details of the external genitalia were found to be useful in segregating three forms viz., cyrus, stichius and romulus belonging to this species. The biology took 34-38 days for completion.

Key words: External genitalia, Butterfly, Papilio polytes, Taxonomy.
\end{abstract}

\section{Introduction}

The Genus Papilio belonging to the tribe Papilionini was erected by Linnaeus (1758) in his book entitled 'Systema Naturae'. The Tribe Papilionini is classified into 2 Genera viz., Papilio and Chilasa based mainly on the pattern of oblique bands in the larva. Based on wing venation, Hemming (1934) divided Papilio into 6 groups to include the 32 species. Of these, 9 species viz., Papilio liomedon, P. polymnestor, P. helenus, $P$. polytes, P. dravidarum, P. demoleus, P. crino, P. buddha and P. paris are found in Kerala. Papilio polytes, which is a tailed swallow-tail butterfly, was first described by Linnaeus in Systema Naturae (1758) and Talbot (1939) reported it from Kerala.

The Common Mormon is a good example for sexual polymorphism and Batesian mimicry. It has four forms- three female forms and one male form; The female form cyrus, is similar to the male form both in colouration and form, stichius mimics the common Rose and romulus mimics the crimson rose. The males generally involve in mud puddling along with other species of butterflies and both sexes show basking. They usually inhabit home gardens, deciduous forests, riparian forests and evergreen forests. As the immature stages of Common mormon are phytophagous in habits, they also have great economic importance as pests of various crops of agricultural and forestry and occasionally they cause severe damage. For instance, Papilio polytes Linnaeus (Papilionidae), which is a well-known pest of citrus in the Tropical Region (Corbet\& Pendlebury,1992); this feeding adaptation has made P. polytes a potentially serious pest in citrus orchard and young plantations.

Identification of this species is based mainly on the descriptions given by Linnaeus (1758) and Talbot (1939). Considering its economic and ecological significance, a study was recently undertaken on the biology, ecology and taxonomy of this species and the results are presented here.

\section{Materials And Methods}

The sampling of butterflies was done by conducting a field survey in representative habitats in Kerala during 2010-2012. The areas covered included Nilambur, Peechi, Vazhani, Athirappilly, Vazhachal and Thenmala. Morphological studies were made by making microscopic slide mounts of body parts. For preparing slide mounts of the external genitalia, the lower part of the abdomen (from the $7^{\text {th }}$ segment onwards) was removed using micro-needles and treated with $10 \% \mathrm{KOH}$ by gently boiling in a water bath. After appropriate maceration in $\mathrm{KOH}$, the boiling was stopped and the material was thoroughly washed. The external genitalia were then extracted from the abdomen by gently tearing the inter-segmental membranes from and around the organ by using fine forceps and micro needles. After careful cleaning, the genitalia was stained with acid fuschin dissolved in acetic acid and transferred to carbol- xylol for clearing (Carbolic acid and xylem 2:3) and mounted in Canada balsam (Mathew et al 1985).

For studying its biology, eggs were collected from the field and reared in small glass jars, $16 \times 10 \mathrm{~cm}$ in size, covered with a clean, dry cloth and securely fastened with a rubber band. Containers were kept moist by placing a small piece of absorbent tissue holding as much water as will evaporate in 24 hours. All frass and excreta were removed daily and the larvae were provided with fresh leaves of the preferred host plant. The duration of the larval instars was recorded based on observations of the moulted shells of the caterpillar's head that remains inside the container after moulting. The size of the caterpillar (length and breadth), mode of feeding, pupation and emergence were also recorded. On attaining the final instar, the container was provided with a dry twig placed diagonally within the container for giving anchorage to the developing pupa. 
Genus: Papilio

\section{Results And Discussion}

Linnaeus, 1758, Systema Naturae, X: 458, no 203.

Papilio polytes Linnaeus(Common Mormon)

Linnaeus, 1758. Syst. Nat. X: 460

D'Abrera, 1982, Butterflies of the Oriental Region, Part 1: 72

Wynter-Blyth, 1957. Butterflies of the Indian Region, Bombay nat. Hist. Soc., p. 392.

Material in collection: $1 \delta^{\Uparrow} 2$ ㅇ., 23.ix. 10, Peechi; $1 \overbrace{}^{\Uparrow} 1$ ‥, 17.xi.11, Thrissur.

Distribution: Myanmar, Sri Lanka, Nepal, Bhutan, Bangladesh, Pakistan and India. In India it has been reported from Himachal Pradesh to Arunachal Pradesh, Sikkim, Assam, Bombay, Madhya Pradesh and S. India. It is well distributed all over the Western Ghats and has been recorded from Trivandrum, Thenmala, Silent Valley, Nelliyampathy, Athirappilly, and Parambikulam.

Host plants: Glycosmis arborea, Murraya koenigii, Atlantia racemosa, Aegle marmelos, Zanthoxylum rhetsa, Citrus sp. and Triphasia sp.

\section{Descriptions}

Papilio polytes Linnaeus is a black bodied swallowtail butterfly with a wing span of $85.3( \pm 5.25) \mathrm{mm}$. It serves an excellent example of a Batesian mimicry among the Indian butterflies. Adults have slow and graceful flight resemble those of the distasteful Common Rose and Crimson rose. They have the habit of puddling on wet grounds.

\section{Adults: Form cyrus}

Male velvety black with a row of white spots in the middle of hind wing. A series of small white spots present on margins of forewings. On the underside of the hind wing, red marginal crescents were present. Female form is similar to male form but the red crescents are strongly marked on hind wing.

\section{Male genitalia}

Uncus short, of uniform width, blunt and finger-shaped. Tegumen and vinculum with narrow, slender arms. Valvae broad, oval with a broad, sclerotised band bearing a fringe of short setae. Costa distinct with broad sclerotised patches extending upto the margin. Harpe appears as a mouse- shaped structure with the proximal end drawn out into a tail-like structure. Sacculus triangular in shape, with an expanded lobe-like portion reaching the base of the valvae. Saccus U-shaped.

Phallus long and tubular with a pointed tip bearing the membraneous vesica. Basal part handle-shaped having a round tip.

\section{Female genitalia}

Ovipositor lobes oval in outline, slightly sclerotised. Posterior apophyses very short compared to the anterior. Sinus vaginalis well developed. Small, round Ostium very much concealed by proximal margins of the sinus. Ductus bursae very short. Corpus bursae oval in shape. Signum spindle-shaped and lamellate, with well developed sclerotisation on the dorsal surface.

\section{Adults: Form stichius}

The form stichius mimics the Common Rose, Pachliopta aristlochiae. It is black and the forewing with white streaks between veins. Hind wing with 2-6 elongate white markings adjacent to cell.

\section{Female genitalia}

Ovipositor lobes broad, strongly sclerotised, fringed with short hairs and almost round in outline. Posterior apophyses slightly shorter than the anterior. Sinus vaginalis well developed. Ductus bursae short. Corpus bursae large and balloon-shaped. Signum long, narrow and lamellate, with well developed sclerotisation on the dorsal surface.

\section{Adults: Form romulus}

The form romulus mimics the Common Rose, Pachliopta hector. It is black and the forewing with broad irregular white bands. The hindwing with red crescents and red spots.

\section{Female genitalia}

Ovipositor lobes broad with sclerotised sides and thickly fringed with short hairs. Posterior apophyses shorter than the anterior. Sinus vaginalis well developed with lateral thickly sclerotised triangular membraneous 
flaps. Ductus bursae wide and of medium length. Corpus bursae elongated, with the basal half narrower than the apical half. Signum very long, broad in the middle and tapering at the ends.

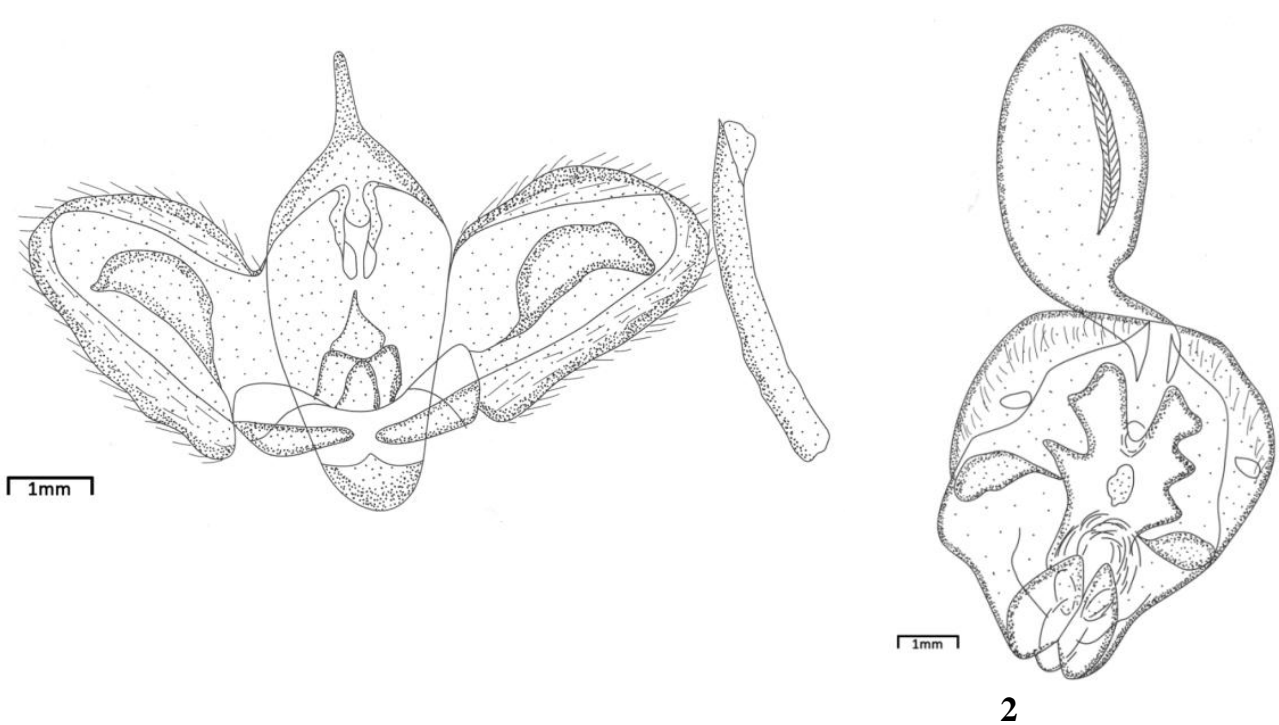

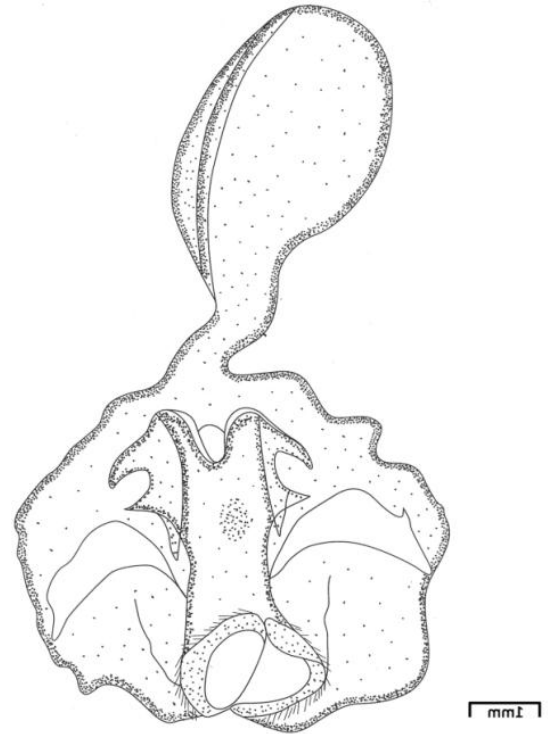

3

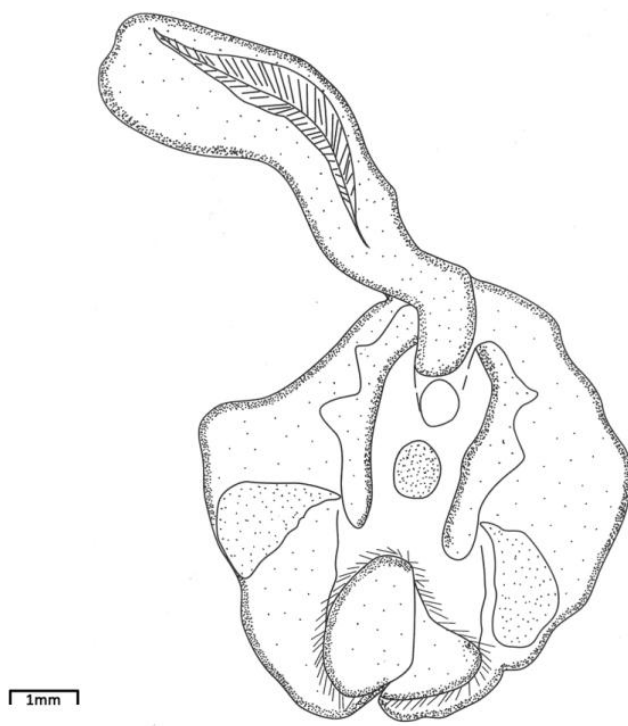

4

Plate I- Fig 1. Male genitalia of $P$. polytes cyrus; 2. Female genitalia of $P$. polytes cyrus; 3 . Female genitalia of $P$. polytes stichius; 4. Female genitalia of $P$. polytes romulus.

\section{Biology of Papilio polytes Linnaeus (Tables 1,2; Pl.ate 2).}

The early stages feed on leaves of plants Glycosmis arborea, Murraya koenigii, Atlantia racemosa, Aegle marmelos, Zanthoxylum rhetsa, and Citrus sp.

Adults: Among the adults, the male has one morph, but the female has three morphs. It has a wing span of 85.3 $( \pm 5.25) \mathrm{mm}$ in expanses and is a tailed black butterfly. In males, upper surface of forewings have a series of white spots which gradually decrease in size towards the apex. The upper sides of the hind wing have a transverse series of discal, elongate white spots. The males are smaller in size than the females. The females exist in three forms, stichius, romulus and cyrus. Of these, the first two are excellent mimics of the Common Rose, Pachliopta aristolochiae and the Crimson Rose, $P$. hector respectively. The third form is almost like the male. 
Egg: The egg is small, spherical, smooth, pale yellow to creamy in colour and laid singly. Gradually the egg fades in colour and first instar visible from outside. The mean incubation period is 3-5 days.

Larva: There are five larval instars. The duration of various instars are presented in Table.19. Detailed description of each instar is given below.

First instar larvae: It measures about $5.9( \pm 0.88) \mathrm{mm}$ in length and $0.76( \pm 0.39) \mathrm{mm}$ in width. The body colour of larvae is light brownish black with dirty white bands present on the last and first abdominal segments. Primary setae were present on the head. The last two abdominal segments had a row of tubercles on each side. Osmetarium present, usually hidden, brown in colour. The larvae less active, sluggish and rests on the upper side of the leaf. Feeding rate was very low. The newly hatched larvae feed on the egg shell. First instar larva feed exclusively on young, soft leaves near the apex of the actively growing branch. The instar lasted for about 2-3 days. Towards the end of instar, the larva attaches itself to a leaf or side of bottle and spins moulting mat.

Second instar larvae: The larva measured $10( \pm 0.94) \mathrm{mm}$ in length and $2.3( \pm 0.88) \mathrm{mm}$ in width. On the third day, the larvae shed their old skin and head capsules. There was no apparent change in colour and behaviour except in size. Dirty whitish band is more widened. This stage lasted for 2-3 days.

Third instar larvae: Third instar larvae measured about 19.1( \pm 0.88$) \mathrm{mm}$ in length and $4.4( \pm 0.52) \mathrm{mm}$ in width. After the second moult, no drastic change except an additional dirty whitish band or thin streak appear on the lateral side of the body and three pairs of spots on the abdominal segments. The body colour changed to greyish green

Fourth instar larvae: Fourth instar larvae was $23.5( \pm 1.27) \mathrm{mm}$ in length and 6.6. $( \pm 0.70) \mathrm{mm}$ in width. The larva feed voraciously the mature leaves.

Fifth instar larvae: Length of the body was $32.7( \pm 1.25) \mathrm{mm}$ in length and $9.7( \pm 0.67) \mathrm{mm}$ in width. There is a drastic change in colour, appearance and behavior of the caterpillar. The body was pure green in colour with two bands on head region. One band was present in between the eyes and other on the first thoracic segment. Two arch shaped wide bands on the middle part of the abdominal segment were present. Whitish, spongy, broad stripe present on the legs and prologs, running throughout the body.

Table 1.Larval body measurements of $P$. polytes $\mathrm{L}$.

\begin{tabular}{|l|l|l|l|l|l|l|}
\hline \multirow{2}{*}{ Dimensions } & \multicolumn{4}{|l|}{ Length } & \multicolumn{2}{l|}{ Width } \\
\cline { 2 - 7 } & Range & Mean & SD & Range & Mean & SD \\
\hline First Instar & $4-7$ & 5.9 & 0.88 & $0.2-1$ & 0.76 & 0.39 \\
\hline Second Instar & $8-11$ & 10 & 0.94 & $2-3$ & 2.3 & 0.88 \\
\hline Third Instar & $18-20$ & 19.1 & 0.88 & $4-5$ & 4.4 & 0.52 \\
\hline Fourth Instar & $22-25$ & 23.5 & $1 . .27$ & $6-8$ & 6.6 & 0.70 \\
\hline Fifth Instar & $31-35$ & 32.7 & 1.25 & $9-11$ & 9.7 & 0.67 \\
\hline
\end{tabular}

Table 2.Developmental period of different stages in $P$. polytes $L$.

\begin{tabular}{|l|l|l|l|}
\hline Developmental period & Range & Mean & S.D \\
\hline Incubation period & $3-4$ & 3.63 & 0.52 \\
\hline Larval period & $20-23$ & 21.64 & 0.81 \\
\hline Pupal period & $12-15$ & 13.82 & 0.75 \\
\hline $\begin{array}{l}\text { Total period (egg - } \\
\text { adult) }\end{array}$ & $34-38$ & 35.45 & 1.29 \\
\hline
\end{tabular}

Pupae: Pupa was smooth, arch shaped, bent inwards mid- ventrally and green in colour. Two light green patch present on the mid -dorsal side. Pupa had 22.2( \pm .92$) \mathrm{mm}$ in length. Before eclosion pupae turns black in colour. Pupal stage lasted for 13-15 days after which adult hatched out.

Lifecycle: The life cycle completed within $35.45( \pm 0.83)$ days. The duration of various stages is given in table 2 .

\section{Ecology}

Papilio polytes Linnaeus are found in diverse habitats ranging from woody plains to moist deciduous patches. They are more abundant during monsoon and post monsoon seasons. Both sexes are seen to feed on the flowers of a variety of plants including Lantana camara, Ixora sp. Clerodendrum capitatum, Cassia sp etc. Based on their sightings during surveys, their flight activity is maximum between 9 am to $2 \mathrm{pm}$. The territorial behaviour is well known in the Papilionidae (Tyler et al. 1994) and is also found in this species. Males made in patrols in defending territory from others. The incidence of parasites is an important aspect to be considered while rearing the immature forms because the original stock is invariably taken from field. It is also noted the 
incidence of parasites in Papilio polytes (Hymenoptera; Ishneumonidae) as indicated in parenthesis. In the field condition, in addition to the parasitic attack, various predatory birds and garden geckos were also found to affect the butterfly population. Usually the palatable species (mostly belonging to genus Graphium, Chilasa) were found to suffer maximum attack since the unpalatable ones (especially the Troidinii) were avoided by the predators.

\section{Conclusion}

Since butterflies visit flowers for nector, they are valuable pollinators. They are very fragile in nature and have even slight perturbations may affect their composition. As a result they are looked upon as good indicators of environmental quality. Because of their short life cycle, they are good candidates for the topics such as genetics, insect - plant interactions and co-evolution. However due to large scale destruction of habitat, due to various developmental activities of man, many species of butterflies are on the verge of extinction. It has been estimated that there has been a loss of $50 \%$ forest cover in the past 50 years in the Western Ghats (Goanker 1996). Therefore, we need to generate information on the impact of habitat disturbances on the survival of butterflies. Varshney (1986) has reported that 2 species of Papilionid butterflies are threatened in India. Due to the large scale ecological disturbances, many more species are facing extinction .Information on the biology and ecology of butterflies are essential in order to develop appropriate conservation strategies. Since the biology of various species differ in different eco- climatic zones, location wise data has to be generated. Information generated in this study will be useful in future conservation programmes.

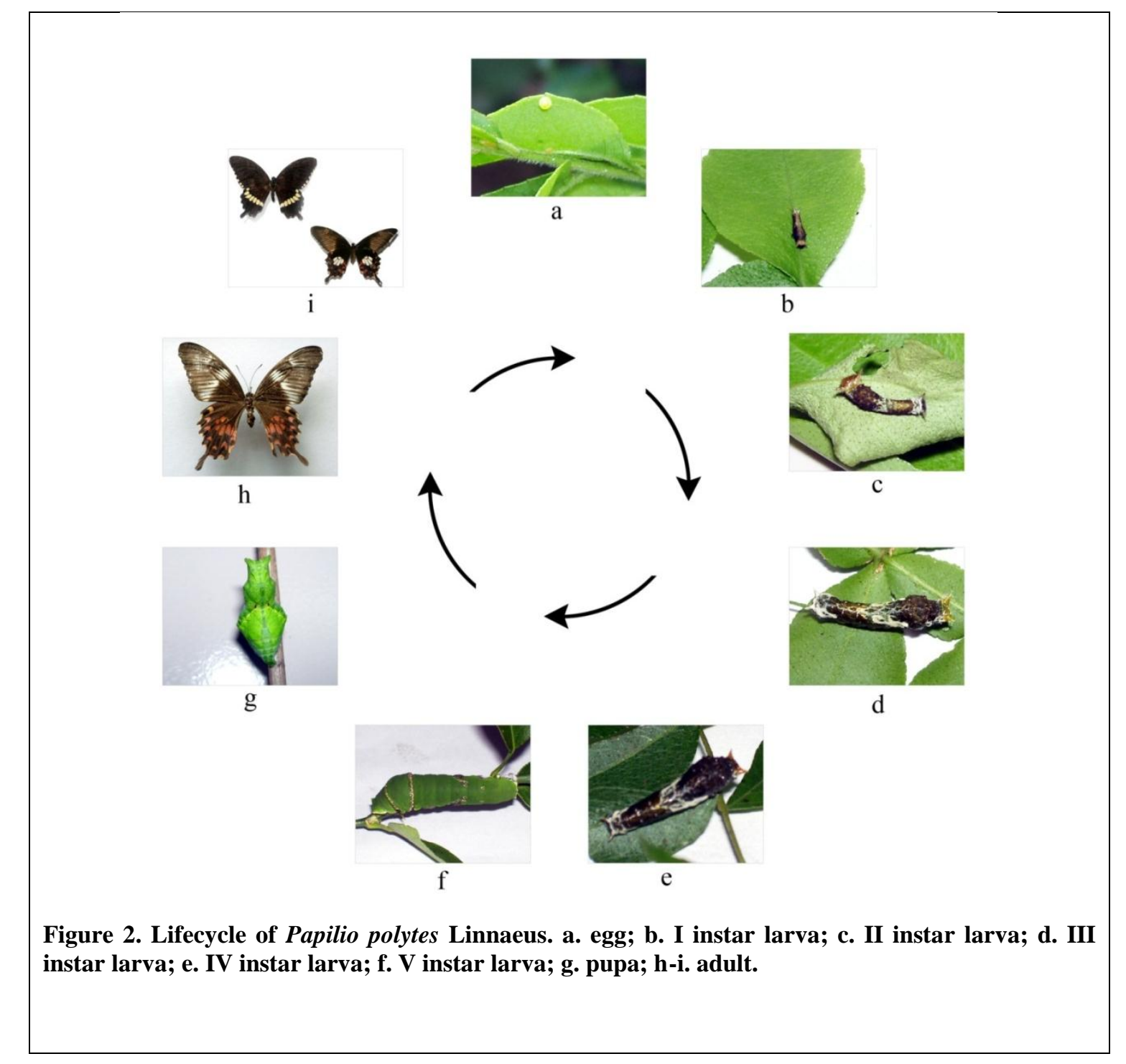




\section{Acknowledgements}

This study formed a part of the Ph.D. research work of the first author, with financial support from the Kerala State Council for Science, Technology and Environment.

\section{References}

[1]. Corbet, A. S. \& H. M. Pendlebury. 1992. The butterflies of the Malay Peninsula. Fourth Edition. Malayan Nature Society. Kuala Lumpur.

[2]. D'Abrera, Bernard, 1982-86.Butterflies of the Oriental Region, Parts I-III, Hill House, Australia.

[3]. George Mathew \& M. G Ramdas Menon. (1985).External genitalia of some Indian Pyralids (Lepidoptera). Journal of Entomological Research, Vol. 9, No. 1, 26-35 pp

[4]. Goanker, H. (1996) Butterflies of Western Ghats, India including SriLanka. A biodiversity assessment of threatened mountain system. Report to the center for ecological science, Bangalore. 86.

[5]. GOI (Government of India), 1982. The Indian Wildlife (Protection) Act, 1982. The Gazette of India (Extra Ordinary), Part II-Section (3), Sub Section (1), Amendment of the Act,1972.

[6]. Hemming, F. 1934. Notes on nine Genera of butterflies. Entomol. 37-38

[7]. Linnaeus, C. 1758. Systema naturae per regna trianaturae. Secundum classes, order, genera, species cum character bus, differentiis, synonymis, locis 106 (eds.) Stockholm. 2 v. (1956 facs. Reprint: Br. Mus. Nat. His. London).

[8]. Talbot, G .1939, Fauna of British India including Ceylon and Burma. Butterflies Vol I. Edited by LT.Col.R.B.S.Sewell, Today and tomorrow's printers and publishers, New Delhi.

[9]. Tyler, H.A., K.S. Brown \& K.H. Wilson. (1994). Swallowtail butterflies of the Americas. Scientific Publishers, Gainesville

[10]. Varshney, R. K. (1986) Threatened butterflies of the Indian region. pp. 104-116 in Majupuria, T. C. (Ed.) Wildlife wealth of India. 656 pp. Tecpress Service L. P., Bangkok.

[11]. Wynter-Blyth, M.A. 1957. Butterflies of the Indian Region, 523 p. Bombay nat. Hist. Soc. Bombay. 